September 9-Governor Clarke proclaims statehood attained for Iowa.

October 26-First election for Iowa state offices.

December 3-Inauguration of a state government.

December 28-Final act of admission of Iowa as a state, by President Polk's approval.

\title{
NAMING OF WISCONSIN AND IOWA
}

Only a few months prior to his death in Dubuque on July 22, 1896, former United States Senator George W. Jones dictated what may have been one of his last letters. It was addressed to his old personal friend, Curator Charles Aldrich of the Iowa Historical Department, and was in response to an inquiry from $\mathrm{Mr}$. Aldrich regarding the naming of the Wisconsin and Iowa territories.

Senator Jones was born at Vincennes, Indiana, April 12, 1804. He was a drummer boy in the war of 1812, and won distinction in the Black Hawk war in Illinois and Wisconsin. He was the last delegate in congress from Michigan territory, the first delegate from Wisconsin territory and one of the first United States Senators from the state of Iowa in 1848 , to which position he was re-elected.

No other man from Iowa enjoyed a more distinguished and colorful public career. At the time of his death his friend, Major C. D. Ham, wrote and there was published in the Dubuque Herald a detailed account of his useful public service, which was reprinted in THE ANNALS, Vol. II, No. 7, pp. 563-5.

Following is the letter of Senator Jones to Mr. Aldrich, which has never heretofore been published:

Hon. Cha's Aldrich,

Dubuque, Iowa, April 8th, 1896.

Des Moines, Iowa.

My dear Friend:

Your kind note of the 7th ins't has just been received \& I immediately reply to it, to say that I gave the name to the Terri- 
tory of Wisconsin, because Pierre Marquette, the Catholic priest gave that euphoneous name to the largest river in its border.

For a like reason I gave the name of Iowa to the territory on the 4 th of July 1838 , when I had that territory created by congress, as her delegate.

As I understand, when the old blind chief of the Sax \& Fox nation led his followers across the Mississippi river, he asked his braves, "what is to be seen here in the Mississippi and Iowa valleys?" They answered: "the land is filled with potatoes, strawberries, immense trees of hickory, walnuts, cherries, grape vines and other valuable esculents." He replied: "This is Iowa, the land where we will pitch our wigwams. We will travel no further towards the setting sun, but make this our last home for all time to come; for you tell me the land is also covered with herds of roving buffalo, deer, elk, antelope, and the rivers \& lakes are filled with fish, beavrs, otters \& various other animals on which we can live."

My eyesight is so impaired as not to enable me to see to read or write, although I may be enabled to so sign my name as that you may read it, although I cannot. I remain, your old friend.

\section{Very sincerely}

Geo. W. Jones

My son acts as my amanuensis and it is embarrassing to me to have to dictate it to him.

\section{AN IOWA PROPHET}

Emlin McClain, chief justice of the Iowa supreme court and long-time chancellor of the law department of the State University of Iowa, in a historic address on "The Introduction of the Common Law into Iowa," delivered April 5, 1892, suggested that "the civilization of the future will not be with those peoples where it has now reached the highest point," and added:

"Indeed, I think it takes no strongly prophetic eye to see the prospect, at least, that in the future some Slavic or other race, now deemed little better than barbaric, will have outstripped not only the Latin, but the. Teuton as well, in the struggle for ultimate supremacy. The race of the finest nerve is not likely to be that of the longest endurance." 
Copyright of Annals of Iowa is the property of State of Iowa, by \& through the State Historical Society of Iowa and its content may not be copied or emailed to multiple sites or posted to a listserv without the copyright holder's express written permission. However, users may print, download, or email articles for individual use. 